\title{
The Role Of Literacy In The Economic Growth Of Cameroon
}

\author{
Dudjo Yen G. Boris, Assistant Lecturer \\ Sonkeng Germain, Lecturer \\ University of Dschang/IUT-FV of Bandjoun, Cameroon \\ Njong Mom Aloysius, Associate Professor \\ Tafah Edokat O. Edward, Professor \\ University of Bamenda, Cameroon
}

URL:http://dx.doi.org/10.19044/esj.2018.v14n22p25

\begin{abstract}
This paper focuses on how education contributes to economic growth. That is to say that there is a significant relationship between the variables of education and the economic growth of Cameroon. Education is therefore a priority for all nations. This shows the prominent place it occupies in the Constitution of almost every state. There are several studies that have focused on the relationship between education and economic growth of the microeconomic perspective, as macroeconomic, both theoretically and empirically. Empirical studies, which have been carried out everywhere around the world, do not agree with the fact that education has a positive effect on economic growth. The estimation results show that literacy rate, however, remains ambiguous and contradictory when OLS is going to GMM. Investing in Literacy is a challenge for development and it is the heart of poverty reduction process at all levels.
\end{abstract}

Keywords: Literacy, Economic Growth, GMM, Development, Education

\section{INTRODUCTION}

Literacy has always been regarded as the necessary precondition for the development of the society. Thus, it plays a significant role in achieving the structural changes in all social, economic, and cultural fields. The contribution of education to economic growth has been recognized and praised by international organizations and governments. The importance of the role of education is supported by economic theory. The fight against poverty and an increase in productivity, individual income, and that of the national economy is possible through the implementation of literacy. In such a context, it is not surprising that literacy occupies a prominent place in economic policy, both 
macro and micro. However, the fact is that over the last twenty years, education policy has boomed in all countries of the world and particularly in sub-Saharan Africa. Countries are trying to invest more in human capital; that is to say in the acquisition of knowledge and skills. This is because they may have realized that it is currently impossible to speak of economic growth without resorting to education.

As opined by Sen, A.K. (1999), the human development theory is interested in measuring the well-being of human, and it shows that social capital and education can participate in the growth of human capital. This approach relies on the existence of externalities of education that do not have a strict economic domain. Improving the literacy rate is indeed a factor that affects development through its effects on health, reproductive status, and participation of women in the labor market and democracy. Equally, it is also an indicator for development.

The central idea is that literacy is a person releasing factor, while freedom of choice constitutes and promotes development. It is therefore difficult to establish clearly a positive relationship between education and growth in developing countries (PVD). This situation has been confirmed by the empirical studies applied to these economies (Barro, 1991; Lau, Jamison \& Louat, 1991; Mankiw, Romer \& Weil, 1992; Benhabib \& Spiegel, 1994), especially since they have focused on cross-sectional data (mixing different levels of the development of countries). Furthermore, education-related growth in developing countries requires further reflection.

Education has a positive influence on the growth rate of the economy. The education-growth relationship has thus constructed a theoretical point of view. These analysis tracks developed autonomous ways, which shows the positive impact of education on the level or rate of growth. It remains, however, so vague in some parts of the world. And if one believes these empirical studies, education can only exert a very limited influence (or no influence) within African countries (Barro, 1991; Lau, Jamison \& Louat, 1992; Mankiw, Romer \& Weil, 1992; Benhabib \& Spiegel, 1994; etc.). How then do we explain this paradox? Equally, how do we explain the African specificity?

If these various attributes of Education are recognized by all and are shown theoretically (Lucas, 1988; Romer, 1990; Aghion \& Howitt, 1991), the fact still remains that the empirical validation of this relationship remains delicate. This deficiency is linked to several factors, and the most important include our views. Firstly, the diversity of systems is involved where institutional aspects are often neglected in empirical studies. Thereafter, there is also the difficulty of identifying the transmission channels through which education can influence growth. Finally, by focusing on developing countries, as is the case of this work, we encounter the traditional difficulties that concern 
the lack of consistent data over relatively long periods, or the structural changes in these countries and the relative newness of their economies.

In this context, the development of literacy is certainly one area of central interest in economic policy in the coming years. Literacy can be severely limited if other factors and complementary products are essential to the growth process such as basic infrastructure, the effects of macroeconomic conditions (price shocks, growth volatility, market distortions), or political instability (including violence) which are not taken into account. Efforts in favor of the education sector must go hand in hand with investment in other social sectors. Literacy as one of the major elements of economic system is an important component of development in poor economies that are far behind. Nevertheless, the relationship is not mechanical and it underpins economic solid base and a stimulating environment.

The literacy triptych, growth, and development processes are not the easiest to highlight. But these features are important and allow to better take into account the different elements that make a coherent development and social asset. Literacy is a profitable economic investment from the point of view of society than from an individual point of view. Yet still, why do some countries experience a high level of wealth even as others continue to be impoverished? What explanation can the economists give these inequalities of development?

Therefore, this paper focuses on assessing the impact of literacy on the economic growth of Cameroon, using an annual time series data from 1980 to 2013. The first part presents the literature review while the methodology is exposed in the second part. The analysis and interpretation of results are proposed in the third part.

\section{LITERATURE REVIEW}

\section{1-1.The Macro-econometric Studies (Worldwide)}

The awareness of the existence between education and growth or the importance of the contribution of education to the creation of material wealth is attributed to the contribution of empirical observations and theoretical investigations. On the theoretical basis, having long ignored the possible influence of knowledge on the process of growth, economists have gradually become aware of the role it could play in the economy. With the theories of human capital (Schultz, 1961; Becker, 1962), endogenous growth (Lucas, 1988; Romer, 1990; Rebelo, 1991; etc.) and empirical estimates (Mankiw et al., 1992; Benhabib \& Spiegel, 1994; Islam, 1995; Lucas, 1988; etc.), knowledge is placed at the heart of the growth process.

The first works having integrated education among the explanatory variables in the growth rate of per capita income in the cross-sectional analysis dates back to the late 70s. Thus, Hicks (1979) had already demonstrated a 
positive connection between the literacy, the rate of primary school enrollment, and economic growth. The study conducted on behalf of the World Bank (Hicks, 1979) leads us to believe that variations in life expectancy from one country to another are more closely correlated with literacy rates. Thus, this was with factors such as calorific and protein intake, consumption of drinking water, the number of doctors per capita, or more generally the Gross National Product (GNP). Among thirty studies on the issue analyzed by Jean-Christophe Dumont (2002), a dozen of these studies were interested in the variables at the beginning of the period. That of Hicks (1979) conducted in 69 countries over the period of 1960-1973 is particularly interesting. Indeed, econometric tests are applied to the initial rate of school enrollment, literacy, and life expectancy indicators at the beginning of the period. Hicks highlighted that only the impact of life expectancy on the product by head over the period dominates.

In his analysis, Romer (1989) sought to verify the empirical validation of his previous theoretical model by drifting back the literacy rate in 1960 on product growth rate per capita investment in 94 countries between 1960 and 1985. The education variable in these models positively affects economic growth, but its impact is not significant. Based on a large sample of poor countries and rich countries from international data, Summers and Heston (1988) and Romer (1989) has deepened the convergence test of economies and concluded that absolute convergence does not hold in cases of large heterogeneous sample of countries. More precisely, Romer found that there was no significant correlation between initial income levels and subsequent growth rates.

Barro (1991) studies have estimated in a cross sectional manner the growth rate of the product per head on the period of 1960 to 1985 for 98 countries using the initial values of the rate of primary and secondary school enrollment, the literacy rate, the ratio of supervision, the mortality rate between zero and 4 years, and fertility rate. Also, Barro introduced elsewhere two characteristics indicators of Africa and Latin America. The results of this study show that the initial rate of primary and secondary school enrollment (1960) presented positive effects on growth over the period of 1960-1985, showing 0.0323 and 0.027 respectively. On the other hand, the staff ratio has negative effects on primary schools, and they are not significant for the secondary schools. The effects of the literacy rate are negative when other variables are introduced into the model.

Mankiw et al. (1990), in their attempt to test the link and educational growth, found a positive and significant effect on the level of human capital (and not in the growth rate of the latter), measured by the number of years of average studies among the active population at the beginning of the period considered based on the average growth rate of GDP/head. Their results were 
questioned in the article by Benhabib and Spiegel (1994), who had presented to honor a more "technological" vision on the role of education in economic growth. Hence, this was developed in an embryo way by Nelson and Phelps (1966). They include critical ways motivated by the example of the diffusion of innovations in agriculture. Studies have indeed shown that they are the most educated farmers who adopt new products and produce first, and that the least educated farmers would adapt to technical progress much later.

Subsequently, there is a relevant line of research in endogenous growth started by a short paper of Nelson and Phelps (1966). Thus, their studies are complementarity between R\&D and investments in human capital. Within this approach, human capital is not "simply another factor in growth accounting". This is because it facilitates technology adoption and diffusion. In particular, a model developed by Redding (1996) analyzes, within an imperfect labor market, low-skill and low-quality traps caused by a strategic complementarity between homogeneous human capital (chosen by workers) and R\&D (provided by firms). Redding uses the Nash Equilibrium solution to solve for rational expectations equilibrium. Scicchitano (2010) extended Redding (1996) by introducing the heterogeneity of the human capital, through education and on-the job training. The paper concludes, differently from the previous study, that complementarity between heterogeneous human capital and R\&D generates several equilibria of the economy's rate of growth. Moreover, in the Redding's model, the absence of the R\&D was a necessary and sufficient condition for the low development trap. In the Scicchitano's model, the lack of innovations becomes necessary but is not a sufficient condition because a technology-specific training is necessary.

\section{1-2. Specifics of Developed Countries}

It is difficult to establish empirically and clearly a positive relationship between literacy and growth in developed countries. This is confirmed by empirical studies in these economies especially since this latter is focused on a cross-sectional data (mixing of countries with very different levels of development). The exercise seems risky and prudence remains of rigor.

In a study on the link between literacy and economic growth achieved from the International Survey of Adult Literacy (EIAA), Coulombe et al. (2004) concluded that the differences between the average levels of skills in OECD countries realized $55 \%$ of the disparities between the growth rates for the period of 1960-1994. Bourdon (1999), Islam (1995), Teal (2010), and Borensztein, DE Gregorio and Lee (1994) have reached conflicting results regarding the role of education in economic growth. The relationship between these two variables is either positive or negative.

Some studies such as Temple (2001), De La Fuente and Ciccone (2003), Cohen and Soto (2001), Krueger and Lindahl (2001), Soto (2002), and 
Aghion and Cohen (2004), using more improved data, more sophisticated techniques and correcting measurement errors, did not provide a relatively clear answer to the contribution of education to economic growth. Although some international comparative studies have shown that many educational variables were key factors in the growth of per capita GDP countries (Barro, 1991; Mankiw et al., 1992), data problems led to numerous limitations. Educational variables such as enrollment or the average number of school years are imprecise indicators to the extent of human capital on education.

Academic economists have traditionally been inclined to consider educational expenditure as an essential element of national investment. This was with substantial results in terms of growth of production. Also, they have been often assigned to the accumulation of human capital a central role in the models, in particular, in the recent literature relating to the endogenous growth. This optimism was confirmed by a first series of international empirical studies on the determinants of growth. However, it was found concordantly that various indicators of education had the expected positive effect. A second series of studies of this type, however, produced somewhat disappointing results using more sophisticated econometric techniques, which even led some researchers to explicitly put into question the relationship between education and growth.

Moreover, economic development seems to have a significant influence in the role given to higher education (Aghion \& Cohen, 2004). In fact, they point out the impact of technological development level in the growth process. For them, depending on the degree of development of a country, the role of education is different. For richer countries known as "close to the technological frontier", the objective is to maintain the economic level reached, in order to remain competitive and to calmly face the constraints of competition. They will thus engage in conduct innovation and creativity by promoting higher education and research. For less developed countries, the aim will instead be to achieve the level of development of the richer countries. They will thus have a catch-up behavior and imitation. In this way, they will favor the financing and development of primary and secondary instruction. Demeulemeester and Rochat (2003) also show in their empirical analysis on Australia, Sweden, and the United Kingdom that according to the history and characteristics of the country, higher education does not contribute identically to the country's development. For Africa, growth is essential to ensure that the continent came out of poverty. Additionally, education is very crucial.

\section{1-3. Specific to Developing Countries}

Very few theoretical models are specifically interested in assessing the relationship between literacy and economic growth in developing countries. This is because of the poverty statistics on the educational and social variables 
especially in Africa. Authors who have dared to take an interest in this issue have been severely criticized and their findings are often crude. We noticed in this category global analysis, where African data is considered as a whole among the other developing countries. Among these analyses, four particularly attract our attention. This includes the analysis of Baldacci et al. (2008) on social spending, human capital and growth in developing countries, including a large sample of African countries. This is in addition to the study of Psacharopoulos (1985) and Freeman and Lindauer (1999), which addresses all the countries involved in the development process including Africa.

In addressing the problem from a comparative perspective, Baldacci et al. (2008) examined, using a panel of 118 developing countries, the various transmission channels of social spending and human capital on growth and the effects of an alternative policy of public intervention. The results show that spending on education and health positively affects the accumulation of human capital and are therefore associated with strong economic growth. Alternatively, the authors showed that alternative policies to improve economic governance and control of inflation produce the same effects as the first.

Freeman and Lindauer (1999) show that the role of education in Africa remains ambiguous. For these authors, if education is crucial to growth, low rates for African countries were the cause of the poor performance observed in the region. Also, the empirical explanations given by economic analyses about this continent, formulated from econometric models, are not convincing. For the functional forms of education, equation relating growth tends to exclude other potential factors of Africa's growth. This weakness models to accurately account for the specific phenomena of growth in Africa, and it however puts into question the role of education in the continent. The results of the study of Freeman and Lindauer (1999) show that the relative variations in the growth of education were positively correlated with economic growth, although these results are dependent on the functional form of the equation used.

Indeed, Psacharopoulos and Woodhall (1985), by applying the method of Schultz to developing countries, got a positive contribution of education to economic growth of around $23.2 \%$ in Ghana and $16 \%$ in Nigeria. Ndongu (1998) in his studies on Kenya has a contradiction of human capital to GDP growth of around $2.25 \%$. He concludes that expenditure on education improves human capital and eventually economic growth. Ngwa Jackson (2005) found that the direct effect of human capital on the growth in overall productivity in Cameroon between 1960 and 2001 is more important than the direct effect of the capacity for innovation (Public Expenditure on Higher Education Research). 
Tafah-Edokat (1998) studied the private returns to investment in education in Cameroon. However, it got the same conclusions as the study of Psachoropoulos (1994): The returns to education are positive and in some cases higher than the returns on investment in other sectors of the economy. The yield of primary education is higher than that of secondary education, which is itself higher than that of higher education. Thus, he concluded just as Psacharopoulos that education, especially primary education, should be a high priority in development policies. The results show that an additional year in school increases earnings between $5 \%$ and $16 \%$ depending on the level of study. In 1995, he managed to establish a positive relationship between real income and primary school enrollment rates in Cameroon (Tafah Edokat, 1995). In a study conducted in Cameroon between 1980 and 2004, the literacy rate is positive and significant around $1 \%$ with a coefficient of 0.038 (Dudjo, 2009). Thus, education is a very important factor for the reduction of poverty. Academic success enhances the potential gains of individuals and it thus increases their gains definitely, which helps them to get out of poverty (Njong, 2010).

In recent studies, Pritchett (2001) and Doudjidingao (2009) stated that macroeconomic returns to education are very low, especially when tested on panel data, thus doubting the results of Barro (1991) on a large sample of developing countries. In addition, education based on revenue performance measure is not very suitable to African countries because of high unemployment and the predominance of the public sector on one hand. On the other hand, it happens because of the emergence of the informal sector which popularizes self-employment. Additionally, low education enrollment would be linked to the poor quality of the whole country.

Bertoni et al. (2018) studied the impact of the Boko Haram conflict on various educational outcomes of children living in North-East Nigeria during the period of 2009-2016. Using an individual panel fixed-effects regression and exploiting both over-time and within-district variation in household-level conflict exposure, they show that conflict reduces school enrollment and increases the probability of school dropout. In addition, being used as a standard difference in "difference estimation strategy", the authors show that conflict reduces the years of completion of education.

In general studies on Africa, accounting for growth are not numerous in empirical studies relative to OECD countries. This finding is not because economists do not care about Africa, but this is justified by the unavailability of data for African countries. This unavailability of data does not provide the opportunity for a wide range of studies on Africa. Nevertheless, some authors had an interest in the relationship between education and economic growth on the African continent. Ndulu and O'Connell (2005) carried out studies on 27 countries of Sub-Saharan Africa by studying the link between education and 
economic growth of these countries considering the period of 1960-2000. They found different results for Sub-Saharan countries. The effects of education on the most significant economic growth were obtained by the authors in order of magnitude for the following countries; Nigeria (whose contribution to growth is $60 \%)$, Côte d'Ivoire (38\%), South Africa (37\%), Kenya (31\%), Mozambique (28\%), Ethiopia (26\%), Cameroon (25\%), Malawi $(11 \%)$, and Tanzania (4.54). For countries in the CFA zone, we noted that the contribution of education to economic growth is more important than for Côte d'Ivoire and Cameroon. The contribution for Latin America comes in second in this study with $37 \%$, and is successively followed by the contributions of education to economic growth in the Middle East, North Africa and Turkey $(17 \%)$, South Asia (13\%), and East Asia and the Pacific (12\%).

\section{METHODOLOGY}

\section{2-1. Data Source and Model Specification}

Data Source: The data used in econometric estimates are derived from three main sources. The data on GDP, domestic private investment, public investment, the labor force and life expectancy were taken from the database of the World Bank "World Development Indicator" dated 2014. Data on openness, civil liberties, technological knowledge, and the emission of carbon dioxide were collected from the website of the University of Sherbrooke and the National Institute of Statistics of Cameroon.

Model Specification: The basic model used for the econometric estimates are based on the work of North (1990), Sow (2006), and Siddiqui et al. (2011). These studies explore the complementary role of literacy on economic growth. The authors use time series and cross-sectional data for the period 1970-2011. Given the similarity of economies, re-specified model will be utilized. But beyond investment, trade openness and civil liberties, we introduce additional variables such as the emission of carbon dioxide and technological knowledge to test the impact on growth.

The structure of our model, which assumes a linear form, is as follows: Ln GDP / head $=\mathrm{f}\left(\mathrm{c}^{\mathrm{t}}\right.$, LIT, NFFDI, PUBIN, DPI, LIFEX, QE, OPEN, CRISIS, DEV) (1)

However, this is written in its linear formulation as:

Ln GDP/head $\mathbf{h}_{\mathbf{t}}=\mathrm{d}_{0}+\mathrm{d}_{1} \ln \operatorname{liT}_{\mathrm{t}}+\mathrm{d}_{2} \operatorname{lnNFFDI}_{\mathrm{t}}+\mathrm{d}_{3} \ln _{\ln } \mathrm{PBIN}_{\mathrm{t}}+\mathrm{d}_{4} \ln _{\mathrm{nDPI}}+$ $\mathrm{d}_{5} \ln \mathrm{QQ}_{\mathrm{t}}+\mathrm{d}_{6} \operatorname{lnOPEN}_{\mathrm{t}}+\mathrm{d}_{7} \ln \operatorname{LIFEX}_{\mathrm{t}}+\mathrm{d}_{8} \mathrm{CRISIS}_{+} \mathrm{d}_{9} \mathrm{DEV}+\varepsilon_{\mathrm{t}}$

Equation (2) indicates the co integration relationship, while equation (3) below reflects the existence of an error correction mechanism. These equations will be used for both the OLS GMM. The OLS estimators seem not to be robust. To work around potential endogeneity bias, we associated the generalized method of moments that seems robust and efficient. 
$\Delta$ Ln GDP/head ${ }_{\mathbf{t}}=\mathrm{d}_{0}+\mathrm{d}_{1} \Delta \operatorname{lnLIT}_{\mathrm{t}}+\mathrm{d}_{2} \Delta \operatorname{lnNFFDI}_{\mathrm{t}}+\mathrm{d}_{3} \Delta \ln$ PUBIN $_{\mathrm{t}}$ $+\mathrm{d}_{4} \Delta \operatorname{lnLDPI}+\mathrm{d}_{5} \Delta \operatorname{lnEQ}_{\mathrm{t}}+\mathrm{d}_{6} \Delta \operatorname{lnOPEN}_{\mathrm{t}}+\mathrm{d}_{7} \Delta \ln \operatorname{liFEX}_{\mathrm{t}}+\mathrm{d}_{8} \mathrm{CRISIS}_{+}$ $\mathrm{d} 9 \mathrm{DEV}+\mathrm{a}_{10} \Delta \hat{\mathrm{e}}_{\mathrm{t}-1}+\varepsilon_{\mathrm{t}}$

$a_{10}$ represents the value that shows the recall rate at the long-term equilibrium of endogenous variable. It must be significantly different from zero to validate the existence of an error correction mechanism.

$\Delta$ represents the first difference of each variable to which it is assigned, and $\varepsilon_{\mathrm{t}}$ represents the error term response to conventional assumptions.

\section{2-2. Estimation Technique Applied to the Model and Choice of Variables}

\section{2-2-1. Estimation Technique Applied to the Model}

This section examines the various factors that affect significantly the level of real GDP per capita in Cameroon. Recall that the variables are assumed a priori act on real GDP per capita. Here, we will determine a longterm relationship between the variables by Ordinary Least Squares (OLS). The Engle and Granger representation theorem states that in the presence of varying co integrated, an error correction representation (ECM) is not only suitable to describe the dynamics of the system, but also the long-term equilibrium to which it converges. Besides the OLS, we also used the generalized moment method (GMM) to compare the estimated results of the estimate. The introduction of the lagged endogenous variables can render obsolete the use of OLS since they do not allow obtaining convergence, which equally justifies the use of GMM.

\section{2-2-2. The Choice Variables}

\section{The Endogenous Variable}

Gross Domestic Product: A year does not go by without our system of measurement being challenged. GDP is the measure of the most widely used economic activity. Its calculation is governed by international standards and a whole work of reflection has sought to define the statistical and conceptual bases.

\section{The Exogenous Variables}

Literacy: Economic studies have long emphasized the importance of literacy in the contribution of skills and know-how essential to economic production. The sign of literacy is positive because it is believed to be an important link in the economic activity (Altilnok, 2007).

Life Expectancy at Birth: This indicator is frequently quoted as a general measure of the quality of life of a population. There is increasing evidence that life expectancy at birth varies by education level of individuals 
(Barro \& Lee, 2001). Expressed in years, life expectancy at birth is expected with a positive sign.

Trade Openness: It facilitates the ability of economies to use foreign technologies, and thus has a positive effect on their growth through technological catch-up effect and improving the productivity of human capital. The effect of the opening is mixed (Stiglitz \& Charlton, 2005).

Net Flows of Foreign Direct Investment (FDI): Foreign direct investment is a lever for the business of health capital and a pattern for further postgraduate studies. Thus, education systems that emphasize training based on the acquisition of general knowledge of the Latin-type benefit less virtuous effects of FDI, when compared to those that focus on vocational training adapted to labor market needs. The expected sign for this variable is positive (Bende et al., 2000).

Public Investment as a Percentage of GDP: Public investment seems to be the foundation of the welfare of the public company. It is used to create the necessary conditions for a functioning economy, to provide public access to safe drinking water and facilitate the transport of goods and people. The sign of the coefficient should be positive.

Domestic Private Investment as Percentage of GDP: It plays a decisive role in the development of our societies. It is important because it boosts development. Its sign should be positive as it is not only involved in the production process, but it is also involved in improving the structure of the economy.

Crisis: This is an economic fact that marked significantly the Cameroonian economy. Therefore, it is important to evaluate its impact on health in Cameroon. It is a dummy variable taking the value " 0 " from 1980 to 1985 and to " 1 " from 1986, during the date of declaration of the crisis. Its sign should be negative.

Environmental Quality: Approximated by carbon dioxide emissions, degradation of the quality of the environment is partly due to the intervention of man and the unsustainable exploitation of the environment and natural resources that provide only short-term benefits to people engaged in it. Its sign should be negative.

Devaluation: This involves translated changing of the nominal exchange rate of the CFA franc. It is considered a dummy variable taking the value of 0 from 1980 to 1993 and 1 from 1994, during devaluation. Its sign should be positive. Its goal is to make the economy competitive.

After defining the variables, we have presented their abbreviations and summary statistics for the variables in Tables a and b, respectively. 
Table 1a. List of variables

\begin{tabular}{|l|l|l|}
\hline Variables & Abbreviations & Measures \\
\hline Literacy & LIT & Literacy rate \\
\hline Health & LIFEX & Life expectancy rates \\
\hline \multicolumn{1}{|c|}{ Public investment } & PUBIN & As \% of GDP \\
\hline Domestic private investment & DPI & As \% of GDP \\
\hline Trade openness & OPEN & (Export + import) / GDP \\
\hline Crisis & CRISIS & Economic crisis 1986 \\
\hline Devaluation & DEV & Devaluation of the CFA Franc 1994 \\
\hline Net flows of Foreign Direct Investment & NFFDI & As \% of GDP \\
\hline GDP Rate & RGDP & $\left(\mathrm{GDP}_{\mathrm{t}}-\mathrm{GDP}_{\mathrm{t}-1}\right) / \mathrm{GDP}$ t-1 \\
\hline Environmental quality & EQ & In metric tons of CO2 emsions \\
\hline
\end{tabular}

Source: Authors

Table 1b. Summary of the main descriptive statistics of the model

\begin{tabular}{|l|c|c|c|c|c|}
\hline \multicolumn{1}{|c|}{ Variables } & Observations & Mean & Std. Dev & Minimum & Maximum \\
\hline Literacy & 34 years & 61.65265 & 9.369031 & 43.30000 & 73.40000 \\
\hline Health & 34 years & 52.81912 & 0.913148 & 51.21000 & 55.03000 \\
\hline \multicolumn{1}{|c|}{ Public investment } & 34 years & 6.267647 & 6.461434 & 0.5000000 & 21.30000 \\
\hline $\begin{array}{l}\text { Domestic private } \\
\text { investment }\end{array}$ & 34 years & 12.50294 & 3.477241 & 6.5000000 & 18.00000 \\
\hline Trade openness & 34 years & 49.11118 & 10.46905 & 31.75000 & 65.02000 \\
\hline Crisis & 34 years & 0.794118 & 0.410426 & 0.0000000 & 1.000000 \\
\hline Devaluation & 34 years & 0.588235 & 0.499554 & 0.000000 & 1.000000 \\
\hline $\begin{array}{l}\text { Net flows of Foreign } \\
\text { Direct Investment }\end{array}$ & 34 years & 1.225588 & 1.402630 & -1.010000 & 5.500000 \\
\hline GDP Rate & 34 years & 3.094282 & 3.978074 & -5.549097 & 9.660981 \\
\hline Environmental quality & 34 years & 3.622400 & 0.216202 & 3.045714 & 3.994097 \\
\hline
\end{tabular}

Source: Authors

Table $1 \mathrm{~b}$ provides a summary of the main descriptive statistics of the model. The average growth rate per capita is $3.094 \%$. The standard deviation of this same variable is relatively high $(3.97 \%)$, indicating a high volatility of growth over the period 1980-2013. Average literacy and life expectancy rates are also $61.65 \%$ and 52.81 years respectively, which appear to be important variables in boosting economic growth despite the low life expectancy of the population. Average foreign direct and public investment rates are low $(1.22 \%$ and $6.26 \%$ ). The respective differences of these variables are high. The standard deviations are different from the averages.

Table 2. Expected Signs

\begin{tabular}{|c|c|}
\hline X & RGDP \\
\hline LIT & + \\
\hline LIFEX & + \\
\hline DPI & + \\
\hline PUBIN & + \\
\hline CRISIS & + \\
\hline DEV & + \\
\hline OPEN & $+/-$ \\
\hline NFFDI & - \\
\hline EQ & \\
\hline
\end{tabular}

Source : Authors 


\section{PRESENTATION OF THE RESULTS}

We will first proceed to test stationary of series used to avoid spurious regressions. This will allow us in a second time to estimate the long-term and short-term model to finally make the presentation and analysis of our results.

\section{3-1. Results of the Stationary Tests}

The results of stationary tests are shown in the following table:

Table 3. Stationary test results

\begin{tabular}{|l|l|l|l|l|l|l|l|}
\hline \multirow{2}{*}{ Variables } & \multicolumn{2}{|l|}{ In Level } & \multicolumn{2}{l|}{ In 1st difference } & In second difference & Conclusion \\
\cline { 2 - 8 } & DFA & PP & DFA & PP & DFA & PP & \\
\hline LIT & $-0,792$ & $-0,790$ & $-4,515^{\mathrm{b}}$ & $-4,490^{\mathrm{b}}$ & & & $\mathrm{I}(1)$ \\
\hline NFFDI & $-2,604$ & $-1,921$ & $-11,184^{\mathrm{b}}$ & $-11,140^{\mathrm{b}}$ & & & $\mathrm{I}(1)$ \\
\hline PUBIN & $-2,953$ & $-1,164$ & $-5,198^{\mathrm{b}}$ & $-5,202^{\mathrm{b}}$ & & & $\mathrm{I}(1)$ \\
\hline DPI & $-1,535$ & $-1,541$ & $-5,798^{\mathrm{b}}$ & $-5,817^{\mathrm{b}}$ & & & $\mathrm{I}(1)$ \\
\hline OPEN & $-1,692$ & $-1,780$ & $-5,464^{\mathrm{b}}$ & $-5,575^{\mathrm{b}}$ & & & $\mathrm{I}(1)$ \\
\hline LIFEX & $-1,414$ & $-1,251$ & $-4,058^{\mathrm{b}}$ & $-4,227^{\mathrm{b}}$ & & & $\mathrm{I}(1)$ \\
\hline RGDP & $-1,170$ & $-1,300$ & $-4,960^{\mathrm{b}}$ & $-4,961^{\mathrm{b}}$ & & & $\mathrm{I}(1)$ \\
\hline EQ & $-0,917$ & $-2,990$ & $-6,637^{\mathrm{b}}$ & $-10,222^{\mathrm{b}}$ & & & $\mathrm{I}(1)$ \\
\hline
\end{tabular}

Source: Output Eviews

From Table 3, it appears that all variables are integrated of order one (I (1)), that is to say non-stationary in level but stationary after the first difference at the 5\% threshold. Thus, we can consider the study of the cointegrating variables and propose, if necessary, an error correction model to estimate this equation.

\section{3-2. Presentation of the Results of the Regression}

The procedure involves using OLS and the GMM from Eviews 7.1 software to estimate model parameters.

The results of the analysis are as follows:

Table 4. Results of OLS estimators and GMM

\begin{tabular}{|c|c|c|}
\hline \multirow{2}{*}{$\begin{array}{c}\text { Eariable } \\
\text { Exogenous variables }\end{array}$} & OLS & GPD/Head \\
\cline { 2 - 3 } & & 11,4797 \\
\hline C & $-2,5812$ & $(2,7951)^{\mathrm{b}}$ \\
\hline LIT & $(-0,2284)$ & $-0,9295$ \\
& 0,0797 & $(-1,6025)$ \\
\hline NFFDI & $(0,0427)$ & $-0,0284$ \\
& $-0,0278$ & $(-1,0720)$ \\
\hline DPI & $(-2,2973)^{\mathrm{b}}$ & 0,2903 \\
& 0,0291 & $(2,0443)^{\mathrm{c}}$ \\
\hline PUBIN & $(-0,2180)$ & 0,2620 \\
& $-0,0189$ & $(3,1421)^{\mathrm{a}}$ \\
\hline OPEN & $(0,2955)$ & 0,0148 \\
& $-0,2177$ & $(0,0385)$ \\
\hline
\end{tabular}




\begin{tabular}{|c|c|c|}
\hline LIFEX & $\begin{array}{c}2,9079 \\
(0,4282)\end{array}$ & $\begin{array}{c}-5,8759 \\
(-2,2991)^{\mathrm{b}}\end{array}$ \\
\hline EQ & 0,1938 & 0,6673 \\
$(1,2509)$ & $(3,1967)^{\mathrm{a}}$ \\
\hline DEV & 0,4224 & $-0,1215$ \\
& $(0,3424)$ & $0,5637)$ \\
\hline CRISIS & $-0,3189$ & $(5,4851)^{\mathrm{a}}$ \\
\hline $\mathrm{R}^{2}$ & $(-0,2871)$ & 0,8000 \\
\hline $\mathrm{R}^{2}$ ajusté & 0,9376 & 0,700 \\
\hline F-Statistic & 0,8930 & $/$ \\
\hline Prob(F-Statistic) & 21,0497 & 1,0400 \\
\hline DW & $(0,00000)$ & 5,0259 \\
\hline J-Statistic & 1,8051 & $(0,2049)$ \\
\hline Pro (F-Statistic) & $/$ & $/$ \\
\hline AR(1) & $/$ & $/$ \\
\hline Inverted AR Roots & 0,8911 & $(4,2652)$ \\
\hline
\end{tabular}

Source: Authors

Since we are dealing with macroeconomic series, it is important to carry out the diagnostic tests before proceeding with the model validation tests.

\section{3-3. Tests Diagnostics Error Terms}

\section{The Significance Test of Individual Coefficients}

On reading this table (Appendix 1-1), only the variable FDI is significant with a negative sign. The other variables have different signs and are not significant for the OLS. Regarding GMM, we noted that the life expectancy, the quality of the environment and public investments, domestic private investment, and the crisis are significant at different thresholds and they also have different signs. However, the other variables are not significant.

\section{Fisher Test, Self Test Correlation Durbin Watson, Variance Analysis and Quality Adjustment}

- Fisher's Test: Fisher's test (0.000001) indicates that the dependent variables together explain the independent variable. This probability is less than 5\%. The generalized method of moments that presents the J-statistical probability is 0.2049 and is greater than the 5\% threshold. Also, the hypothesis of validity of instruments appears to be consistent.

- Autocorrelation Test Durbin Watson: The DW statistic is equal to 1.805 ; it lies in the question area $\left(\mathrm{d}_{1}<\mathrm{DW}<\mathrm{d}_{2}\right)$. Thus, we can conclude that positive autocorrelation of residuals is preferred to dependence presumption 
of error terms for the OLS. GMM is 1.040 and less than 1.15. Thus, we reject $\mathrm{H}_{0}$, and we conclude that there is a positive correlation self residues.

- Analysis of Variance and Quality Adjustment: The determination coefficients for the two methods are: $\mathrm{R}^{2} \mathrm{OLS}=0.9376$ and $\mathrm{R}^{2} \mathrm{GMM}$ $=0.8000$. The values of the coefficients of determination are below DW $=1.36$. The model is valid and the model variables explain almost $94 \%$ of GDP growth per capita for OLS and $80 \%$ for GMM. The adjusted $\mathrm{R}^{2}$ statistics for both methods are 0.8930 (OLS) and 0.7000 (GMM), respectively. This seems to better reflect the true performance of the equation. The values of both $\mathrm{R}^{2}$ and adjusted $\mathrm{R}^{2}$ statistics are very close, and this implies that the model is well specified.

\section{Normality Test, Ljung-Box Test, Breusch Golfrey-Test and Test of Heteroscedasticity}

- Tests of Normality: The J-B statistic is 1.576 and 0.454 probability of which is greater than $5 \%$, and then we can accept the null hypothesis of normality of error terms or residuals.

- Test Ljung-Box: The Q statistic Ljung -Box for a delay equals to 20, which confirms the absence of autocorrelation of the residuals series. Indeed, the probability of the test for a delay equal to 20 is 0.709 higher than 0.05 ; so the null hypothesis of white noise residuals is accepted.

- Test Breusch-Golfrey: At the end of this test, the probability of the testBreusch Golfrey exceeds 5\%, which means that the null hypothesis of no autocorrelation of error terms is accepted (Prob Chi-Square $(2)=0.5986$ ).

Breusch-Godfrey Serial Correlation LM Test

\begin{tabular}{cccc}
\hline \hline F-statistic & 0.256867 & Prob. F(2,12) & 0.7776 \\
Obs*R-squared & 1.026339 & Prob. Chi-Square(2) & 0.5986 \\
\hline \hline
\end{tabular}

- Heteroscedastic Test: The probability of the test 0.4731 is greater than $5 \%$. It accepts the null hypothesis of homoscedasticity residues or error terms.

Test Heteroskedasticity: White

\begin{tabular}{cccc}
\hline \hline F-statistic & 0.877810 & Prob. F(10,14) & 0.5731 \\
Obs*R-squared & 9.634361 & Prob. Chi-Square(10) & 0.4731 \\
Scaled explained SS & 1.196513 & Prob. Chi-Square(10) & 0.9996 \\
\hline \hline
\end{tabular}

\section{3-4. Economic Interpretation}

We hypothesized that the literacy rate has a positive and significant impact on GDP / head. In our model, the coefficient on this variable is negative for GMM and positive for OLS, and is not significant for both methods joining the work of Teal (2010) and Islam (1995). It seems that the positive coefficient 
of literacy could be explained by the resources freed by heavily indebted poor Countries (HIPC) debt relief that came timely. Also, it massively increased the share of public resources allocated to education. Educational reforms in Cameroon following the debt relief program have indeed significantly increased school provision but its quality is still low. Hence, its negativity is presented by GMM.

The coefficient of life expectancy positively affects economic growth with the OLS and negatively with GMM. The mixed result is similar to Ulmann (2003). Cameroon, which aspires to become the emergence in a little over 15 years, should invest more in human capital that is essential for economic growth. But the negativity offered by GMM shows that low public resources are not always allocated where needs are greatest. Yet an economy that does not have a workforce with a minimum level of education and health is not able to follow a proper sustainable growth path.

The negative coefficient of the opening could be explained by the virtuous cycle whereby a small aperture does not enhance the economic development, which in turn does not produce trade. This sign is contrary to our expectations such as Hartwig (2009) and at the same time not significant. She drove down 0.217 percentage point of economic development for OLS. The GMM has an expected sign for this variable and is insignificant as stated by Weil (2007). The opening leads to the improvement of the business environment. It provides access to knowledge through foreign goods imported, and it is also necessary in the enterprise production process.

The variable foreign direct investment, contrary to what we expected, shows a negative sign, which could be explained by the low diversity of economic activities. The country has an export-oriented economy and agricultural raw materials, and does not promote participation rates in companies. We also noted the poor endowment of skilled labor and the lack of resources that can be devoted to the development of a genuine policy of Research and Development.

Regarding domestic private investment, it seems to have a positive impact for both methods and is only significant for the GMM. Note that it is not affected by the literacy rate in our country, which consequently limits a significant contribution to economic growth. Its positive impact is reduced because the $10 \%$ increase of this variable induces a GDP per capita of $0.290 \%$ for GMM.

The coefficient of public investment is in the order of -0.0189 with a probability of 0.7719 . This reflects a negative sign and shows that it is not significantly related to economic growth for OLS. For the generalized method of moments, we found a positive and significant relationship. This is due to the low capacity of the country to better conduct its strategies infrastructural matter given its level of development. 
Note that the quality of the environment influences positively and significantly the economic development of GMM; for OLS, we noted that it is not significant although it is positive. This result is not consistent with the expected sign. Indeed, this pollution affects the productivity of agents or child absenteeism in school. Pollution is considered an inevitable cost in the industrialization process.

Regarding the devaluation, the two methods have different results (positive for OLS and negative for GMM) and are not material. However, the devaluation has positive economic implications by improving public finances and agricultural products, but this poses risk in an environment of volatile world prices and it further weakens government revenues.

The negative coefficient of the crisis is expected. It can be seen that it is not significant and long term, and it does not have a considerable impact despite lower economic development of the order of 0.3189 percentage point it entails. This negative and insignificant coefficient is presented by the OLS and it is positive and significant for GMM.

The stationary test indicates that the residue is stationary to different thresholds $(1 \%, 5 \%$ and $10 \%)$ of the significance of which t-Statistic value is -8.342. We can then estimate a model called error correction model (ECM) which integrates the values variation in levels.

Null Hypothesis: D(RESID) has a unit root

Exogenous: Constant

Lag Length: 0 (Automatic - based on SIC, maxlag = 8)

\begin{tabular}{cccc}
\hline \hline & t-Statistic & Prob.* \\
\hline \hline \multicolumn{2}{c}{ Augmented Dickey-Fuller test statistic } & -8.342691 & 0.0000 \\
\hline Test critical values: & 1\% level & -3.661661 & \\
& 5\% level & -2.960411 & \\
& $10 \%$ level & -2.619160 & \\
\hline \hline
\end{tabular}

*MacKinnon (1996) one-sided p-values.

\section{Estimated Error Correction Model}

The short term pattern is generated by an error correction mechanism. The results of the model estimation are as follows: 
Table 5. Results of OLS estimators and GMM

\begin{tabular}{|c|c|c|}
\hline \multirow{2}{*}{$\begin{array}{l}\text { Endogenous variable } \\
\text { Exogenous variables }\end{array}$} & \multicolumn{2}{|c|}{ GDP/head } \\
\hline & OLS & GMM \\
\hline $\mathrm{C}$ & $\begin{array}{c}4,4165 \\
(0,2884)\end{array}$ & $\begin{array}{c}5,5823 \\
(2,2734)^{\mathrm{b}}\end{array}$ \\
\hline $\mathrm{D}(\operatorname{lnLIT})$ & $\begin{array}{l}-0,2428 \\
(0,0552) \\
\end{array}$ & $\begin{array}{c}-0,6698 \\
(-1,3453) \\
\end{array}$ \\
\hline $\mathrm{D}(\operatorname{lnNFFDI})$ & $\begin{array}{c}-0,0441 \\
(-1,2317) \\
\end{array}$ & $\begin{array}{c}-0,0136 \\
(-1,5343) \\
\end{array}$ \\
\hline $\mathrm{D}(\operatorname{lnDPI})$ & $\begin{array}{c}-0,0809 \\
(-0,1529) \\
\end{array}$ & $\begin{array}{c}0,3051 \\
(2,7859)^{\mathrm{b}} \\
\end{array}$ \\
\hline $\mathrm{D}(\ln P U B I N)$ & $\begin{array}{c}0,0216 \\
(0,0922)\end{array}$ & $\begin{array}{c}0,0477 \\
(1,0529)\end{array}$ \\
\hline $\mathrm{D}(\operatorname{lnOPEN})$ & $\begin{array}{c}-0,5223 \\
(-0,9156) \\
\end{array}$ & $\begin{array}{c}-0,3194 \\
(2,3013)^{b} \\
\end{array}$ \\
\hline $\mathrm{D}(\operatorname{lnLIFEX})$ & $\begin{array}{l}13,5188 \\
(0,9455) \\
\end{array}$ & $\begin{array}{c}-3,1135 \\
(-2,2553)^{\mathrm{b}} \\
\end{array}$ \\
\hline $\mathrm{D}(\operatorname{lnEQ})$ & $\begin{array}{c}0,2171 \\
(0,5900) \\
\end{array}$ & $\begin{array}{c}0,1579 \\
(2,0671)^{\mathrm{c}} \\
\end{array}$ \\
\hline CRISIS & $\begin{array}{l}-0,4576 \\
(-1,3515)\end{array}$ & $\begin{array}{c}0,2120 \\
(2,7880)^{\mathrm{b}}\end{array}$ \\
\hline DEV & I & $\begin{array}{c}-0,0753 \\
(-1,4754) \\
\end{array}$ \\
\hline Resid1(-1) & $\begin{array}{c}-0,2886 \\
(-0,2885)^{\mathrm{c}}\end{array}$ & I \\
\hline $\mathrm{D}(\operatorname{lnGDP} /$ head (-1)) & I & $\begin{array}{c}0,7918 \\
(9,7459)^{\mathrm{b}}\end{array}$ \\
\hline $\mathrm{D}(\operatorname{lnOPEN}(-1))$ & $\begin{array}{c}0,1528 \\
(0,4848) \\
\end{array}$ & I \\
\hline $\mathrm{D}(\operatorname{lnPDPI}(-1))$ & $\begin{array}{c}0,5786 \\
(0,9107) \\
\end{array}$ & l \\
\hline $\mathrm{D}(\ln P U B I N(-1))$ & $\begin{array}{c}-0,2089 \\
(-1,0828) \\
\end{array}$ & I \\
\hline $\mathrm{D}(\operatorname{lnNFFDI}(-1))$ & $\begin{array}{c}-0,0024 \\
(-0,0443)\end{array}$ & I \\
\hline $\mathrm{D}(\operatorname{lnLIFEX}(-1))$ & $\begin{array}{l}-55,3293 \\
(-1,1059) \\
\end{array}$ & I \\
\hline $\mathrm{D}(\operatorname{lnLIT}(-1))$ & $\begin{array}{c}1,0130 \\
(0,2467) \\
\end{array}$ & l \\
\hline $\mathrm{D}(\operatorname{lnEQ}(-1))$ & $\begin{array}{c}-0,0242 \\
(-0,0734) \\
\end{array}$ & l \\
\hline $\operatorname{AR}(1)$ & $\begin{array}{c}-0,2529 \\
(-0,4562) \\
\end{array}$ & I \\
\hline $\mathrm{R}^{2}$ & 0,9852 & 0,9200 \\
\hline $\mathrm{R}^{2}$ ajusté & 0,9019 & 0,8585 \\
\hline F-Stat & 11,8253 & 1 \\
\hline Prob(F-Stat) & 0,0324 & 1 \\
\hline DW & 2,15 & 1,26 \\
\hline J-stat & 1 & 7,29 \\
\hline Prob(J-Stat) & 1 & 0,6063 \\
\hline Inverted AR Roots & -25 & 1 \\
\hline
\end{tabular}

Source : Authors 
It appears from the analysis of this table that:

- $\mathrm{R}^{2} \mathrm{MCO}=0.9852$ and $\mathrm{R}^{2} \mathrm{GMM}=0.9200$ show that the model variables explain up to $98 \%$ and $92 \%$ GDP per capita respectively for the OLS and GMM.

- Probability (F-statistic) $=0.0324$ indicates that the overall regression is significant at the 5\% level. Probability $(\mathrm{J}$-statistic $)=0.6063$ is greater than $5 \%$ indicates that the instruments appear to be valid.

- The DW statistic for this model is superior to the values of coefficients of determination, and the errors are not autocorrelated. We also noted that the adjusted $\mathrm{R}^{2}$ exceeds $85 \%$ for both methods. The coefficient of the restoring force of offset residue of a period [GDP $(-1)=-0.2886$ ] is negative and only significant for OLS.

- Errors are homoskedastic according to the White heteroskedasticity test at the $5 \%$ because

$$
\text { Prob }=0.2649>0.05 \text {. }
$$

- Prob $=0.1604>0.05$; the autocorrelation test Breusch-Godfrey indicates no autocorrelation of errors. This is confirmed by the highest DW statistic.

- The Normality test Jarque Bera indicates a probability equal to $0.3086>0.05$. The distribution is normal.

- The Probability of Ljung-Box test for a delay equal to 12 is $0.783>$ 0.05 . Thus, it accepts an absence of autocorrelation of the residuals series.

\section{Economic Interpretation}

We noted that all the variables are not significant with OLS, whereas they are mostly with the GMM. Public investment and environmental quality variables have a positive impact on economic growth. The first variable has an expected sign and is not significant for both methods. The second have an unexpected and significant sign with the GMM. The growth is associated with the emergence of new environmental risks linked to pollution, the apparent inability of the country to fight against global warming, deforestation, etc.

Foreign direct investment is negative and not significant. Its coefficient is similar to long-term analysis. It caused a drop of 0.044 percentage point of economic development.

The literacy rate is negative and not significant for both methods. Health has significant virtuous effects on economic growth. Although this view is confirmed in the OLS approach, the weakness of these negative coefficients obtained by GMM reveals an ambiguity as to the quality of infrastructure and lack of qualified staff in certain specialties. The mismatch between training and the labor market, mismanagement, and corruption are all phenomena that explain the inefficiency of public spending. 
It should be noted that the domestic private investment and openness have little influence on GDP per head with the OLS. As for the generalized method of moments, these variables are negative and positive respectively for opening domestic private investment and are all significant at the 5\% level. Given the robustness of the generalized method of moments, we proceed safely with risk to be deceived that the opening may result from the deterioration of exchange rates and significant price fluctuations of raw materials during the past 30 years. Notwithstanding, it allows countries to access knowledge. These variables have beneficial effects on economic growth.

The negative coefficient of the crisis is that which is expected for OLS. It can be seen that it is not significant. Compared to the generalized method of moments, we found that the coefficient is positive and significant.

\section{CONCLUSION}

The debate on the role of literacy is not all clear. Different types of models can be imagined. Although the negative effect was found joining some empirical studies, the debate on the issue is unclear and confusing. It also emerges from the analysis that the investments do not benefit the people who are likely to be the priority beneficiaries in their majority. The most important role for literacy is undoubtedly its contribution to social cohesion and democratic input. The construction of the national identity of a nation is one of the founding elements to which literacy participates in its broadest sense. It is an important catalyst for external effect of other sectors on the process of economic and social growth. Hence, there is a significant importance of combinations with other investments in basic economic infrastructure. To sum it all up, Literacy as one of the pillars of the economic system is necessarily at the center of economic policies. It contributes significantly to improving the living conditions of the population and to build a society based on knowledge.

\section{References:}

1.Aghion, P. \& Howitt, P. (1991). "Growth and Unemployment," CEPR Discussion Papers 577.

2. Aghion, P. \& Cohen, E. (2004). Education et Croissance. La Documentation française, Paris.

3. Altinok, N. (2007). «Capital Humain et Croissance : l'apport des enquêtes internationales sur les acquis des élèves », Juin 2007. IREDU (Institut de Recherche sur l'Education), UMR 5192 CNRS/Université de Bourgogne, Dijon.

4. Baldacci, E., Benedict, C., Gupa, S. \& Cui, Q. (2008). "Social Spending, Human Capital and Growth in Developing countries", World Development, 36(8), p. 1317-1341. 
5. Barro, R. J. (1991). "Economic Growth in a Cross Section of Countries", Quarterly Journal of Economics, 106, p. 407-430.

6. Barro, R. J. \& Lee, J.W. (2001). "International Data on Educational Attainment: Updates and Implications", Oxford Economic Papers 53 July, 541-563.

7. Baumol, W., Sue, A., Batey, B. \& Wolf, E. (1989). "Productivity and American leadership: The long view", MIT press, Cambrigde, Massachusetts, Londres

8. Becker, G. (1962). "Investment in Human Capital: A Theorical Analysis", Journal of Political Economics, 70, p. 9-49.

9. Bertoni, E., Di Maio, M., Molini, V. \& Nistico, R. (2018). Education is forbidden: the effect of the Boko Haram conflict on education in North-East Nigeria. CSEF (Center for Studies in Economics and Finance), Working Papers $\mathrm{N}^{\circ} 495,47$ pages.

10. Bende, N., Ford, J. L. \& Slater, J. R. (2000). "The impact of FDI and regional economic integration on the economic growth of the ASIAN5 Economics, 1970-1994: a comparative analysis in a small structural model", In Ford J. L (ed) Finance, Governance and performance in pacific and south East Asia, Edwar Elgar, pp. 383-99.

11. Benhabib, J. \& Spiegel, M. (1994). "The Role of Human Capital in Economic Development: Evidence from Aggregate Cross- Country Data", Journal of Monetary Economics, 34(2), p. 143-173.

12. Bourdon, J. (1999). « La rentabilité de l'investissement éducatif : un concept de référence dans une réalité changeante ? », In administer, gérer et évaluer les systèmes éducatifs, J.J. Paul, ed., ESF éditeur, paris, pp. 215-248.

13. Borensztein, E., De Gregorio, J. \& Lee, J. W. (1994). "Does Foreign Direct Investment affect Economic Growth?", Document de travail, Fonds monétaire international, Washington D.C., September.

14. Caselli, F., Esquivel, G. \& Lefort, F. (1996). Reopening the Convergence Debate: A New Look at Cross-Country Growth Empirics, Journal of Economic Growth, 1 (3) pp. 363-389

15. Cohen, D. \& Soto, M. (2001). « Growth and human capital: good data, good results", OECD development Center. Technical Papers, $\mathrm{n}^{\circ} 179$.

16. Coulombe, S., Tremblay, J.F. \& Marchand, S. (2004). "Enquête Internationale sur l'Alphabétisation des Adultes: Performance en Littératie, Capital Humain et Croissance dans Quatorze Pays de l'OCDE, Statistique Canada, (89-552), Catalogue 11.

17. De la Fuente, A. \& Cicone, A. (2003). « Human capital in a global and knowledge-based economy", final report, European commission. 
18. Demeulemeester, J. L. \& Rochat, D. (2003). «Les politiques européennes d'éducation et de formation à travers les textes», Agone. Sociology, Histoire et Politique, $\mathrm{n}^{\circ} 29-30$, pp. 59-82.

19. Denison, E. F. (1962). "The sources of economic growth in the United States and alternatives before us", supplementary paper $n^{\circ} 13$, New York, committee for Economic Development.

20. Doudjidingao, A. (2009). Education et croissance en Afrique subsaharienne, thèse de doctorat en sciences économiques. Université Aix-Marseille 2-de la méditerranée.

21. Dudjo, Y. B. (2009). Alphabétisation et Santé comme Vecteurs de Croissance Economique au Cameroun. Thèse de Master, Université de Dschang, Cameroun.

22. Dumont, J.C. (2002). "La contribution des facteurs humains à la croissance : revue des empiriques »CREFA, cahier de recherche, $\mathrm{n}^{\circ}$ 99-10, Université de Laval.

23. Freeman, R. B. \& Lindauer, D. L. (1999). "Why not Africa?”, NBER Working paper $n^{\circ} 6942$

24. Gado, B. M. S. (2000). Education, distribution des revenus et dynamique de la croissance : le cas des pays de la zone CFA, thèse de doctorat, Université de Bourgogne, IREDU CNRS, 309p.

25. Gurgand, M. (2000). «Capital Humain et croissance : la littérature empirique à un tournant ? „Economie Publique, vol.6, p.71-93

26. Hartwig, J. (2009). "Is Health Capital Formation Good for long-term Economic Growth?-Panel Granger-Causality Evidence for OECD Countries", Journal of Macroeconomics, in press, pp. 314-325.

27. Hicks, N. (1979). "Growth vs. Basic Needs: Is There a Trade off ?", World Development, Vol. 7, p. 985-994.

28. Islam, N. (1995). "Growth Empirics: A Panel Data Approach", Quarterly Journal of Economics, 110/4, 1127-1170.

29. Jackson-Ngwa, E. T. (2005). «Education, innovation et croissance économique au Cameroun ». Munich Personal Repec Archive (MPRA). p. 1-17.

30. James, B.A, (2008). Economic development, pollutant emission and energy consumption in Malaysia, Journal of Policy Modeling, (30): 271-278.

31. Kruerger, A. B. \& Lindahl, M. (2001). "Education for Growth: Why and for Whom?" Journal of Economic Literature, Vol. XXXIX, p.1101-1136, December.

32. Kyriacou, G. A. (1991). "Level and growth effects of human capital: A cross-country study of the convergence hypothesis." Working Paper 91- 26, C.V. Starr Center for Applied Economics, New York University. 
33. Landau, D. (1983). "Governement expenditure and economic growth: a cross-country study”, Southern Economic Journal, 49, 783-792.

34. Lau, L., Jamison, D. \& Louat, F. (1991). Education and productivity in developing countries: Aggregate production function approach. Working papers (612), World Bank, Washington, D.C.

35. Lucas, R. (1988). "On the Mechanics of Economic Development", Journal of monetary Economics, 22, pp. 3-42.

36. Mankiw, G., Romer, D. \& Weil, D. (1992). "A Contribution to the Empirics of Economic Growth", The Quarterly Journal of Economics, 107(2): 407-437.

37. Mankiw, G., Romer, D. \& Weil, D. (1990). "A Contribution to the Empirics of Economic Growth," NBER Working Papers 3541, National Bureau of Economic Research, Inc.

38. Ndongu, S. (1998). « Contribution du capital humain à la croissance économique au Kenya », Document de travail, Université de Nairobi

39. Ndulu, B. J. \& O’connell, S. A. (2005). « Policy plus: African growth performance 1960-2000", Draft prepared for the plenary session on explaining African Economic Growth AERC.

40. Nelson, R. \& Phelps, E. (1966). "Investment in Humans, Technological Diffusion and Economic Growth", American Economic Review (61), p. 69-75.

41. Njong Mom, A. (2010). "The effects of educational attainment on poverty reduction in Cameroon" Journal of Education Administration and policy Studies, Vol. 2 (1), pp. 001-008.

42. North, D. (1990). Institutions, Institutional Change and Economic Performance, Cambridge: Cambridge University Press.

43. Pritchett, L. (2001). "Where has All the Education Gone", World Bank Economic Review, 15, p. 367-391.

44. Psacharopoulos, G. (1994). "Returns to Investment in Education: A Global Update", World Development, 22(9), 1325-1343.

45. Psacharopoulos, G. \& Woodhall, M. (1985). «Education pour le développement: une analyse des choix d'investissement », ed. Economica, Paris, pp. 30-73.

46. Psacharopoulos, G. (1985). "Returns to Education: A Further International Update and Implication", The Journal of Human Resources, 20(4), 583-597.

47. Rebelo, S. (1991). "Long-run Policy Analysis and Long-run Growth Models", Journal of Political Economy, 99, p. 3-42.

48. Reddings, S. (1996). Low-Skill, Low-quality trap: strategic complementarities between Human Capital an R\&D, Economic journal, Vol. 106, pp. 458-70. 
49. Romer, P. (1990). "Endogenous Technological Change”, Journal of Political Economic, 98(5): 71-102.

50. Romer, P. (1989). "Human capital and Growth: theory and evidence" Journal of Political Economy, $\mathrm{n}^{\circ} 92$.

51. Scicchitano, S. (2010). Complementary between heterogeneous Human capital and R\&D: Can job-training avoid low development traps? Empirica, 37(4), 361-380.

52. Schultz, T.W. (1961). "Investment in Human Capital", American Economic Review, 51(1), p. 1-17.

53. Sen, A. K. (1999b). «Santé et Développement», Allocation d'orientation, $52^{\mathrm{e}}$ assemblée mondiale de la santé, OMS, Genève, 18 mai.

54. Siddiqui, A. M., Lubna, S. H. \& Atiqur, R. (2011). «Vulnerable Child Laborers from Slum Areas of Meerut city, India: Socio-economic and Health Determinants", Transactions, Inst Indian, Vol. 33 issue (1), pp 123-137.

55. Soto, M. (2002). "Rediscovering Education in Growth Regressions", OECD development centre working papers, No. 202, Editions OCDE

56. Sow, A. (2006). « La contribution des facteurs humains (éducation et santé) à la croissance économique au Sénégal », Mémoire de DEA, Université Gaston Berger.

57. Summers, R. \& Heston, A. (1988). "A new set of international comparisons of real product and price levels estimates for 130 countries", 1950-85, Review and Income and Wealth, 34, 1-26.

58. Stiglitz, J. E. \& Charlton, A. (2005). Pour un Commerce Mondial plus Juste. Traduit de l'anglais américain par Paul CHEMLA, Fayard, France. [titre original : Fair Trade for All. How Trade Can Promote Development, Publié en 2005 par Oxford University Press].

59. Tafah-Edokat, E. O. (1995). "In Income Distribution Effects of Schooling and Implications for Educational Resource Allocation in LDCs: A Case Study of Cameroon" in West Africa Economic Journal, Vol. 8, n¹. pp 23-37.

60. Tafah-Edokat, E. O. (1998). "Rates of Return to Education: A Case study of Cameroon" Unpublished paper, Department of Economics, University of Yaoundé II, Soa.

61. Teal, F, (2010). "Higher education and economic development in Africa: a review of channels and interaction", Centre for the study of African economies, University of Oxford.

62. Temple, J. R. W. (2001). « Effets de l'éducation et du capital social sur la croissance dans les pays de l'OCDE», Revue économique de l'OCDE, n' 33 . 
63. Ulmann, P. (2003). «Economie de la santé : quelques faits stylisés », Econ WPA HEW, 26p. //129.3.20.41/eps/hew/papers/0308/0308002.pdf

64. Weil, D.N. (2007). "Accounting for the Effect of Health on Economic Growth", The Quarterly Journal of Economics, Vol. 122(3), pp. 12651306.

\section{APPENDIX}

\section{Appendix 1 : The Long Term}

Appendix 1-1 : Regression of cointegration

Dependent Variable: LNGDP_HEAD

Method: Least Squares

Sample (adjusted): 19812013

Included observations: 25 after adjustments

Convergence achieved after 31 iterations

\begin{tabular}{crrrr}
\hline \hline Variable & Coefficient & Std. Error & t-Statistic & \multicolumn{1}{c}{ Prob. } \\
\hline \hline LNLIT & 0.079730 & 1.864978 & 0.042751 & 0.9665 \\
LNNFFDI & -0.027801 & 0.012102 & -2.297335 & 0.0375 \\
LNIDPI & 0.029197 & 0.133875 & 0.218088 & 0.8305 \\
LNLIFEX & 2.907925 & 6.790682 & 0.428223 & 0.6750 \\
LNPUBIN & -0.018903 & 0.063955 & -0.295566 & 0.7719 \\
LNOPEN & -0.217776 & 0.168104 & -1.295482 & 0.2161 \\
DEV & 0.422448 & 1.233576 & 0.342458 & 0.7371 \\
LNEQ & 0.193831 & 0.154952 & 1.250914 & 0.2315 \\
CRISIS & -0.318999 & 1.110955 & -0.287139 & 0.7782 \\
C & -2.581265 & 11.30085 & -0.228413 & 0.8226 \\
AR(1) & 0.891146 & 0.208931 & 4.265263 & 0.0008 \\
\hline \hline R-squared & 0.937638 & Mean dependent var & 2.959652 \\
Adjusted R-squared & 0.893094 & S.D. dependent var & 0.102575 \\
S.E. of regression & 0.033538 & Akaike info criterion & -3.652070 \\
Sum squared resid & 0.015748 & Schwarz criterion & -3.115765 \\
Log likelihood & 56.65088 & Hannan-Quinn criter. & -3.503322 \\
F-statistic & 21.04971 & Durbin-Watson stat & 1.805122 \\
Prob(F-statistic) & 0.000001 & & \\
\hline \hline Inverted AR Roots & \multicolumn{5}{|c}{. } & & \\
\hline \hline
\end{tabular}


Appendix 1-2: Normality test

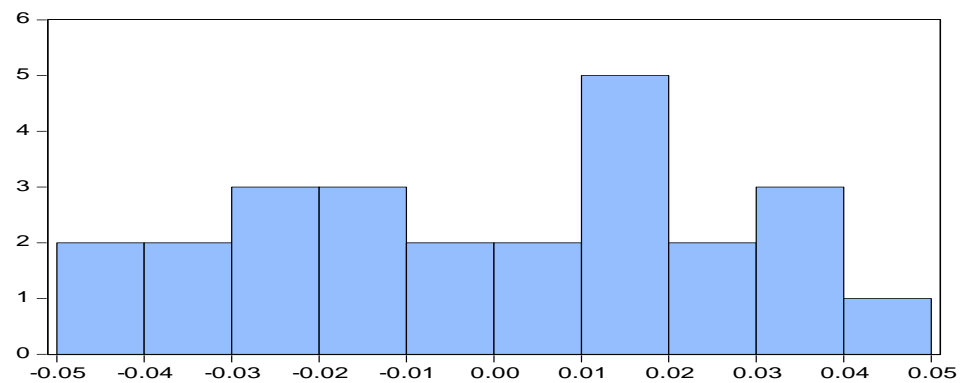

Series: Residuals Sample 19812013 Observations 25

Mean

$3.56 e-10$ Maximum $\quad 0.042209$

Minimum -0.042796

Skewness 0.116210

Kurtosis 1.792042

Jarque-Bera 1.576230 Probability 0.454701

\section{Appendix 1-3: Test of Ljung-Box}

Sample: 19812013

Included observations: 25

Q-statistic

probabilities adjusted for 1 ARMA term(s)

\begin{tabular}{|c|c|c|c|c|c|c|}
\hline Autocorrelation & Partial Correlation & & $\mathrm{AC}$ & PAC & Q-Stat & Prob \\
\hline & & 1 & 0.064 & 0.064 & 0.1159 & \\
\hline$* 1$ & $*$ & 2 & -0.140 & -0.144 & 0.6873 & 0.407 \\
\hline & $\cdot 1^{*}$ & 3 & 0.058 & 0.079 & 0.7905 & 0.674 \\
\hline & * * & 4 & -0.056 & -0.090 & 0.8926 & 0.827 \\
\hline$*$ & $*$ & 5 & -0.099 & -0.069 & 1.2248 & 0.874 \\
\hline & & 6 & -0.036 & -0.050 & 1.2715 & 0.938 \\
\hline & & 7 & 0.036 & 0.028 & 1.3199 & 0.971 \\
\hline & & 8 & -0.035 & -0.048 & 1.3674 & 0.987 \\
\hline & $\left.\cdot\right|^{* *}$ & 9 & 0.316 & 0.343 & 5.5820 & 0.694 \\
\hline & .1 & 10 & 0.057 & -0.039 & 5.7284 & 0.767 \\
\hline & & 11 & -0.058 & 0.059 & 5.8891 & 0.824 \\
\hline & . $*$ & 12 & -0.012 & -0.072 & 5.8963 & 0.880 \\
\hline$\left.\cdot\right|^{*}$ & $\left.\cdot\right|^{* *}$. & 13 & 0.161 & 0.250 & 7.3536 & 0.833 \\
\hline & .1 . & 14 & 0.011 & -0.018 & 7.3614 & 0.883 \\
\hline ***1. & $* *$ & 15 & -0.229 & -0.135 & 10.891 & 0.695 \\
\hline$*$. & $* *$ & 16 & -0.076 & -0.150 & 11.325 & 0.729 \\
\hline & $\left.\cdot\right|^{*}$ & 17 & 0.060 & 0.118 & 11.628 & 0.769 \\
\hline & . * & 18 & 0.025 & -0.113 & 11.686 & 0.819 \\
\hline$* *$ & * $*$ & 19 & -0.177 & -0.184 & 15.205 & 0.648 \\
\hline & . * . & 20 & -0.006 & -0.090 & 15.210 & 0.709 \\
\hline
\end{tabular}


Appendix 1-4: Model estimation by GMM

Dependent Variable: LNGDP_HEAD

Method: Generalized Method of Moments

Sample (adjusted): 19812013

Included observations: 28 after adjustments

Linear estimation with 1 weight update

Estimation weighting matrix: HAC (Bartlett kernel, Newey-West fixed bandwidth $=4.0000$ )

Standard errors \& covariance computed using estimation weighting matrix

Instrument specification: LNGDP_HEAD LNGDPHEADT_1 LNLIT

LNNFFDI

LNDPI LNPUBIN LNLIFEX LNOPEN LNEQ CRISIS DEV C

\begin{tabular}{crrrr}
\hline \hline Variable & Coefficient & Std. Error & t-Statistic & Prob. \\
\hline \hline LNLIT & -0.929593 & 0.580058 & -1.602587 & 0.1264 \\
LNNFFDI & -0.028424 & 0.026514 & -1.072023 & 0.2979 \\
LNIDPI & 0.290391 & 0.142044 & 2.044379 & 0.0558 \\
LNPUBIN & 0.262015 & 0.083387 & 3.142160 & 0.0056 \\
LNLIFEX & -5.875949 & 2.555675 & -2.299177 & 0.0337 \\
LNOPEN & 0.014822 & 0.384207 & 0.038577 & 0.9697 \\
LNEQ & 0.667370 & 0.208764 & 3.196774 & 0.0050 \\
CRISIS & 0.524119 & 0.095552 & 5.485151 & 0.0000 \\
DEV & -0.121517 & 0.077707 & -1.563771 & 0.1353 \\
C & 11.47978 & 4.107037 & 2.795148 & 0.0120 \\
\hline \hline R-squared & 0.800647 & Mean dependent var & 2.962496 \\
Adjusted R-squared & 0.700971 & S.D. dependent var & 0.105110 \\
S.E. of regression & 0.057478 & Sum squared resid & 0.059467 \\
Durbin-Watson stat & 1.040021 & J-statistic & 5.025943 \\
Instrument rank & 11 & Prob(J-statistic) & 0.204970 \\
\hline \hline
\end{tabular}

Appendix 2 : The short term

Annex 2-1: Short-term estimate by OLS

Dependent Variable: DLNGDP_HEAD

Method: Least Squares

Sample (adjusted): 19822013

Included observations: 21 after adjustments

Convergence achieved after 27 iterations

\begin{tabular}{crrrr}
\hline \hline Variable & Coefficient & Std. Error & t-Statistic & Prob. \\
\hline \hline DLNOPEN & -0.522381 & 0.570510 & -0.915638 & 0.4274 \\
DLNDPI & -0.080947 & 0.529241 & -0.152949 & 0.8881 \\
DLNPUBIN & 0.021614 & 0.234396 & 0.092209 & 0.9323 \\
DLNNFFDI & -0.044176 & 0.035863 & -1.231790 & 0.3058 \\
DLNLIFEX & 13.51885 & 16.60293 & 0.945514 & 0.4142 \\
DLNLIT & 0.242836 & 4.395173 & 0.055251 & 0.9594
\end{tabular}




\begin{tabular}{crrrr} 
DLNEQ & 0.217169 & 0.368040 & 0.590070 & 0.5966 \\
CRISIS & -0.457676 & 0.338638 & -1.351523 & 0.2694 \\
C & 4.416556 & 15.31011 & 0.288473 & 0.7918 \\
Resid1(-1) & -0.288642 & 1.000254 & -0.288569 & 0.0917 \\
DLNOUVERT(-1) & 0.152889 & 0.315316 & 0.484877 & 0.6610 \\
DLNIPD(-1) & 0.578670 & 0.635395 & 0.910724 & 0.4296 \\
DLNIPU(-1) & -0.208900 & 0.192913 & -1.082872 & 0.3581 \\
DLNIDE(-1) & -0.002452 & 0.055277 & -0.044358 & 0.9674 \\
DLNESPDEVIE(-1) & -55.32930 & 50.02669 & -1.105996 & 0.3495 \\
DLNALPHA(-1) & 1.013062 & 4.106009 & 0.246727 & 0.8210 \\
DLNQE(-1) & -0.024272 & 0.330428 & -0.073455 & 0.9461 \\
AR(1) & -0.252927 & 0.554321 & -0.456282 & 0.6792 \\
\hline \hline R-squared & 0.985296 & Mean dependent var & 2.952726 \\
Adjusted R-squared & 0.901975 & S.D. dependent var & 0.104050 \\
S.E. of regression & 0.032577 & Akaike info criterion & -4.242042 \\
Sum squared resid & 0.003184 & Schwarz criterion & -3.346737 \\
Log likelihood & 62.54144 & Hannan-Quinn criter. & -4.047738 \\
F-statistic & 11.82530 & Durbin-Watson stat & 2.153590 \\
Prob(F-statistic) & 0.032462 & & \\
\hline \hline
\end{tabular}

Appendixx 2-2: heteroscedasticity test white Heteroskedasticity Test: White

\begin{tabular}{cccc}
\hline \hline F-statistic & 4.367490 & Prob. F(17,3) & 0.1251 \\
Obs*R-squared & 20.18444 & Prob. Chi-Square(17) & 0.2649 \\
Scaled explained SS & 0.369950 & Prob. Chi-Square(17) & 1.0000 \\
\hline \hline
\end{tabular}

Appendix 2-3: Test Breusch-Godrey

Breusch-Godfrey Serial Correlation LM Test:

\begin{tabular}{cccc}
\hline \hline F-statistic & 18.94163 & Prob. F(2,1) & 0.1604 \\
Obs*R-squared & 20.45992 & Prob. Chi-Square(2) & 0.0000 \\
\hline \hline
\end{tabular}

\begin{tabular}{|c|c|c|c|c|c|c|}
\hline $\begin{array}{r}\text { Sampl } \\
\text { Includ } \\
\text { Q-statistic probabilit } \\
\text { adjusted for 1 ARM } \\
\text { term(s) }\end{array}$ & $\begin{array}{l}\text { Appendix } \\
222013 \\
\text { ervations: } 21\end{array}$ & Te & t de $L j \mathbf{v}$ & & & \\
\hline Autocorrelation & Partial Correlation & & $\mathrm{AC}$ & PAC & Q-Stat & Prob \\
\hline$. * 1 . \mid$ &.$*||$. & 1 & -0.191 & -0.191 & 0.8772 & \\
\hline.$* 1.1$ & $. * \mid$ & 2 & -0.099 & -0.140 & 1.1239 & 0.289 \\
\hline.$|*|$ & $.\left.\right|^{*} . \mid$ & 3 & 0.210 & 0.171 & 2.3026 & 0.316 \\
\hline
\end{tabular}




\begin{tabular}{rr|rrrrr}
.$||$. &.$||$. & 4 & -0.016 & 0.052 & 2.3095 & 0.511 \\
.$|* *|$. & $.\left.\right|^{* *} . \mid$ & 5 & 0.253 & 0.326 & 4.2400 & 0.374 \\
.$*||$. &.$*||$. & 6 & -0.200 & -0.144 & 5.5287 & 0.355 \\
.$||$. &.$||$. & 7 & -0.034 & -0.060 & 5.5687 & 0.473 \\
.$||$. &.$*||$. & 8 & 0.031 & -0.184 & 5.6046 & 0.587 \\
.$||$. &.$|*|$. & 9 & 0.054 & 0.104 & 5.7216 & 0.678 \\
.$||$. &.$*||$. & 10 & -0.044 & -0.085 & 5.8083 & 0.759 \\
.$*||$. &.$||$. & 11 & -0.169 & -0.035 & 7.1877 & 0.708 \\
.$||$. &.$*||$. & 12 & 0.016 & -0.117 & 7.2009 & 0.783 \\
\hline
\end{tabular}

Appendix 2-5: Equation estimate first difference GMM

Dependent Variable: DLNGDP_HEAD

Method: Generalized Method of Moments

Sample (adjusted): 19822013

Included observations: 24 after adjustments

Linear estimation with 1 weight update

Estimation weighting matrix: HAC (Bartlett kernel, Newey-West fixed bandwidth $=3.0000)$

Standard errors \& covariance computed using estimation weighting matrix Instrument specification: DLNGDP_HEAD DLNOPEN DLNPUBIN DLNDPI

DLNNFFDI DLNLIFEX DLNLIT DLNEQ CRISIS DEV C DLNGDP_HEAD(-1) DLNOPEN(-1) DLNPUBIN(-1) DLNDPI(-1) DLNNFFDI

-1) DLNLIFEX(-1) DLNLIT(-1) DLNEQ(-1) DLNGDP_HEAD(-2)

\begin{tabular}{crcrc}
\hline \hline Variable & Coefficient & Std. Error & t-Statistic & Prob. \\
\hline \hline DLNOPEN & 0.319425 & 0.138800 & 2.301330 & 0.0386 \\
DLNPUBIN & 0.047747 & 0.045348 & 1.052917 & 0.3116 \\
DLNDPI & 0.305170 & 0.109538 & 2.785974 & 0.0154 \\
DLNNFFDI & -0.013642 & 0.008891 & -1.534332 & 0.1489 \\
DLNLIFEX & -3.113557 & 1.380539 & -2.255320 & 0.0420 \\
DLNLIT & -0.669842 & 0.497911 & -1.345304 & 0.2015 \\
DLNEQ & 0.157900 & 0.076384 & 2.067187 & 0.0592 \\
CRISIS & 0.212080 & 0.076067 & 2.788069 & 0.0154 \\
DEV & -0.075314 & 0.051046 & -1.475407 & 0.1639 \\
C & 5.582344 & 2.455464 & 2.273437 & 0.0406 \\
DLNGDP_HEAD(-1) & 0.791864 & 0.081251 & 9.745957 & 0.0000 \\
\hline \hline R-squared & 0.920046 & Mean dependent var & 2.958823 \\
Adjusted R-squared & 0.858542 & S.D. dependent var & 0.104696 \\
S.E. of regression & 0.039377 & Sum squared resid & 0.020157 \\
Durbin-Watson stat & 1.263927 & J-statistic & 7.295463 \\
Instrument rank & 20 & Prob(J-statistic) & 0.606387 \\
\hline \hline
\end{tabular}

